\title{
What is the Real Tax Burden in Slovakia?
}

\section{Zlatica KONÔPKOVÁ}

Masaryk University, Brno, Czech Republic; konopkova.zlatica@mail.muni.cz

\begin{abstract}
Taxes are the main fiscal instrument and essential part of economy. Every government needs to collect them to fund its spending, but also needs to find the right balance to minimize their negative distortion effects. This paper investigates the real tax burden in Slovakia using modified World Tax Index (WTI). It is a multi-criteria indicator measuring overall tax burden in OECD countries. WTI is constructed as a combination of hard tax data weighted based on factor analysis by soft data, which are gathered through an online questionnaire among tax specialists. WTI eliminates the influence of GDP and does not overestimate the tax burden as other indicators. Results for Slovakia suggest that personal income taxes have the greatest impact, followed by corporate income taxes, property taxes and other taxes on consumption/excise taxes. The lowest tax burden is created by the valueadded tax. The results recommend a decrease in labor income taxes that had increasing trend over investigated period.
\end{abstract}

Keywords: tax burden; tax quota; World Tax Index (WTI); factor analysis; PCA; Slovakia

JEL Classification: H21; C38

\section{Introduction}

Economies and their governments are currently dealing with the consequences and uncertainty caused by the pandemic of novel coronavirus, which highlights the role of the government in economy. Restrictive measures were put in place in order to prevent the spread of the virus and caused reduction of economic activity all over the sectors. Economic subjects now turn their attention to the government and ask for help and compensation for limiting their activities. Therefore, huge pressure is expected on government budgets in next years. Especially on those, who have not recovered completely from the latest global financial crisis. It would be a real challenge for policy makers to set up right mixture of taxes to cover their increased spending and at the same time does not have significant negative impact on economic activity. Taxes can slow down the economic growth, as they create distortions and burden part of the activity in economy.

Due to the negative impact of taxation on economy, it is important to measure the size of impact on economy. The mostly used indicators of tax burden are tax quota and implicit tax rates. Tax quota relates the tax revenues to nominal GDP, or in compound form, tax revenues together with social security contributions to nominal GDP. It is available for many countries, frequently used in models of economic growth and for countries comparison. Implicit tax rate represents also the ratio of tax revenues, but only to the tax related activities or commodities in GDP instead of the whole nominal GDP. The implicit tax rates are calculated for labour, capital 
and consumption, but only for countries in European Union and therefore comparison is possible only within EU.

There are also alternative indicators of tax burden created in order to eliminate some disadvantages of the mentioned standard measurements. Usually, they are not as simple as the standard ones, but might better reflect the phenomenon. Raimondos-Møller and Woodland (2006) introduce an intuitive, non-money metric index of optimality, which measures the distance of a current tax structure from the optimal one, but it says nothing about how costly it is to be away from the optimal level of taxes. Polito (2009) focuses on specific field of taxes and investigate the tax burden by calculating effective tax rates. He argues that effective marginal and average tax rates (as forward-looking indices of the effective tax burden on income from capital) are negatively biased because traditional models overlook dividend constraints associated with financial tax incentives, such as accelerated depreciation. According to De Laet and Wöhlbier (2008), tax is as a compulsory unrequired payment to the government. Tax types are assigned various economic function (work, business, consumption) and differentiated according to the national account. Kiss et al. (2009) criticize the structure of tax quota and eliminate the influence of government.

According to Kotlán and Machová (2012), the tax quota does not reflect the level of the tax burden, but only the redistribution of GDP percentage through the public budgets. A higher tax quota can indicate only more efficient tax collection than higher tax burden. Another disadvantage is connected to GDP, because of its different methodology in different countries. The same is valid also for the implicit tax rates. Therefore, they have introduced their own alternative indicator for OECD countries called World Tax Index (WTI), which is not limited only to the tax revenues and nominal GDP. As presented by Kotlán and Machová (2013), WTI more significantly address the negative effect of taxation for particular taxes types, which is not possible using the tax quota. In Konôpková and Buček (2016), a new methodology for WTI based on applying factor analysis was introduced. The new tax burden indicator is actually a unique single weighted average tax rate for the country. As shown by pilot project results for the Czech Republic in Konôpková and Buček (2018a), modified WTI eliminates the influence of GDP and does not overestimate the tax burden as other indicators.

The goal of this paper is to investigate the tax burden in Slovakia. It follows and extends previously mentioned research and presents the results of applying newly designed WTI for Slovakia. Next section describes methodology and data, then the results are presented and discussed.

\section{Methodology and Data}

WTI is an overall multi-criteria indicator incorporating information from different areas, that might affect the tax burden, e.g. progressivity of the tax system, incentives, deductions, administration, etc. It is structured into 5 main groups according to OECD taxes classification - Personal Income Tax (PIT), Corporate Income Tax (CIT), Value Added Tax (VAT), Individual Property Taxes (PRO) and Other Taxes on Consumption/Excises (OTC). It is calculated as a combination of available hard tax data and soft data (qualified expert opinions - QEO) gained from questionnaires, which are distributed among tax specialists. 
In its original design, WTI methodology was assuming that tax experts can evaluate directly the tax burden in their countries. Therefore, such experts were asked to share their expert judgements about the tax burden in their country, and the mean tax burden was calculated for each tax category based on their answers. Only academic experts were included. New methodology extends the research also to public and private sector and changes from direct to indirect approach. As stated by Borsboom, Mellenbergh, and van Heerden (2003), the values of representing variables are hidden, because human behaviour cannot be observed directly, but they can be estimated through mathematical methods.

A new questionnaire was introduced in Konôpková and Buček (2016) and is available online at http://goo.gl/forms/kWCsMvKO2tWUirlk2. It is built on several “Do you think...?" questions to be answered using a standard Likert scale of Strongly disagree (1) - Strongly agree (5). They represent different components of taxation in order to discover the unobserved underlying factors for every main tax category. Applying the factor analysis, five factors are received and the obtained individual score is then used for calculation of the tax categories weights for each individual respondent. The average value of all respondents is then the final weight for the tax category. Final WTI is calculated as a combination of the standardized weights and representing tax rates for every category. The indicator defined in this way is a unique single weighted average tax rate for the country. It was shown in Konôpková and Buček (2018b) that three different methods of factorization obtain similar effects for the five tax categories and therefore calculation of the WTI is independent of the chosen method of factorization.

This paper presents the results of the Principal Component Analysis (PCA) built in psych library and performed in R-Studio. The Principal Component Analysis (PCA) is a statistical procedure that transforms a number of correlated variables into a (smaller) number of uncorrelated variables. The PCA can be done using the singular value decomposition (SVD):

$$
X=U \Sigma V^{T}
$$

where, $U$ is a $n \times n$ matrix with eigenvectors of $X X^{T}, \Sigma$ is a $n \times p$ diagonal matrix containing the square roots of eigenvalues of $U$ or $V$ in descending order and $V^{T}$ is a $p \times p$ matrix with eigenvectors of $X^{T} X$. For more details, check Brown (2009).

\subsection{Data}

To calculate the final WTI for Slovakia, a representative ad valorem tax rate for each category must be selected. Unfortunately, there is no single tax rate that would represent Excises (OTC). They are mostly per unit taxes defined by law and in Slovakia cover fuel (diesel, petrol), alcohol (hard liquor, wine, and beer), and tobacco (cigarettes). An equivalent ad valorem tax was calculated for every good as a percentage of excise on the average annual price. The final representative tax rate for the OTC category was then calculated as the weighted average of the mentioned equivalent ad valorem taxes. The weights were taken from Harmonised index of consumer prices published by Eurostat (2020). Table 1 displays the names of selected representative tax rates and their source. 
Table 1. Representative tax rates for Slovakia and their source

\begin{tabular}{|l|l|l|}
\hline Category & Description & Source \\
\hline PIT & $\begin{array}{l}\text { Average personal income tax \& social security contribution rates } \\
\text { to gross labour income }(100 \% \text { of the mean wage) }\end{array}$ & OECD (2020), Table I.5 \\
\hline CIT & Statutory corporate income tax rate & OECD (2020), Table II.1 \\
\hline VAT & Basic tax rate & OECD (2020), Table 2.A2.1 \\
\hline PRO & Tax on the acquisition of real property/property transfer tax & Zakonypreludi.sk \\
\hline OTC & The average rate of excise taxes weighted by HICP weights & calculation \\
\hline
\end{tabular}

Figure 1 shows the representative tax rates and their changes over time. The most important is year 2004, when Slovakia has joined European Union and also big tax reform was implemented. All property tax rates were cancelled and one basic flat rate at $19 \%$ was introduced for personal, corporate income and value added taxes. The flat tax rate was cancelled in 2012 and the CIT rate has been significantly increased. In WTI, PIT category covers also social security contributions as special type of tax and therefore it was above flat tax rate. Overall, the PIT rate has increasing trend over time. The increase in OTC was caused by the tax harmonization after the entry of Slovakia into the European Union.

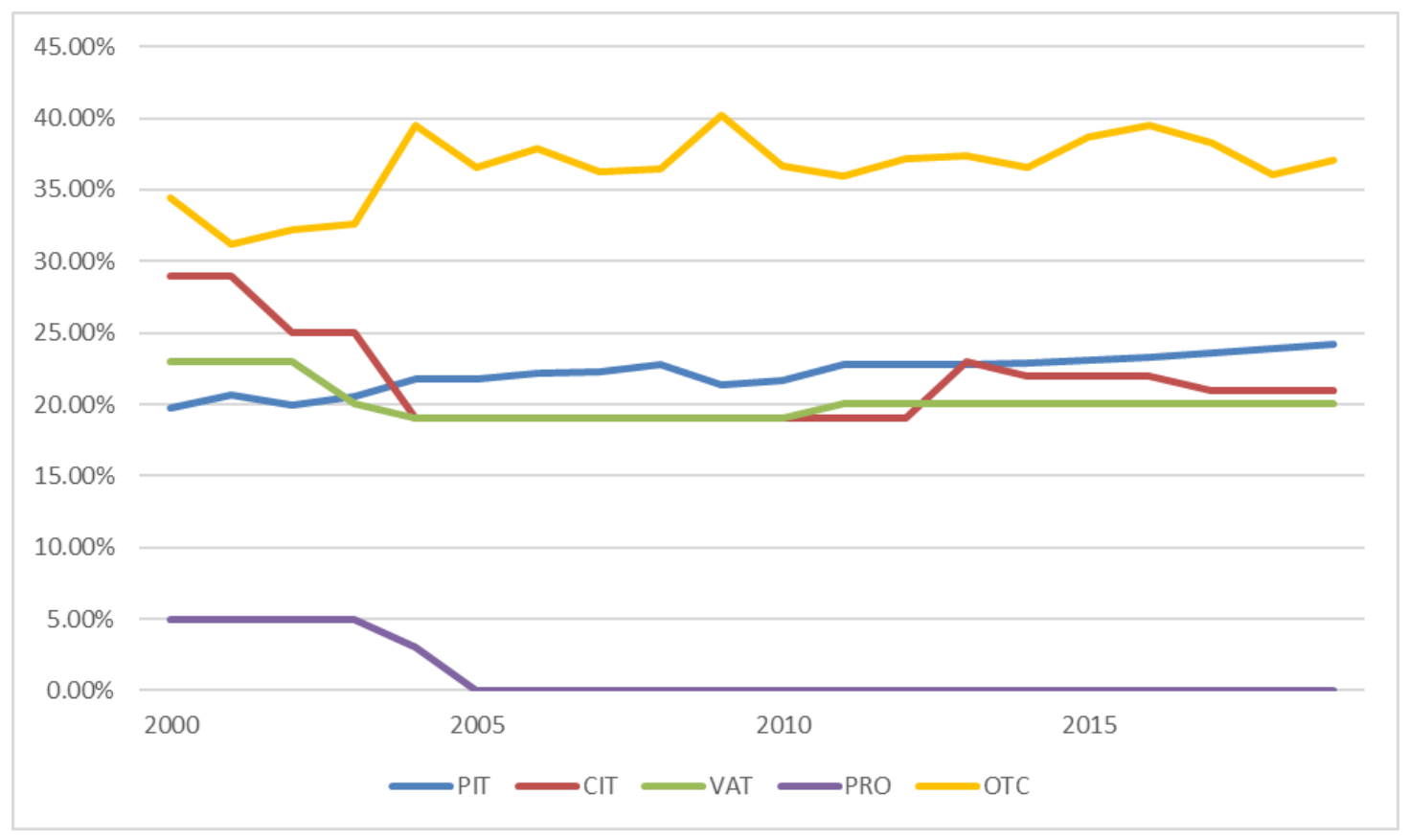

Figure 1. Representative tax rates over time.

\section{Results}

The responses were collected from October 2016 till April 2017 and then mainly in the period from August 2020. Questionnaire was sent to academic researchers, public national institutions, and to the private sector represented by the Big Four accounting firms. It was also shared to tax specialist in cooperation with Slovenská komora daňových poradcov and in the biggest accounting discussion group on social network Facebook.

Together 30 respondents filled the questionnaire, mostly from private sector (83\%). More than $56 \%$ of respondents strongly agreed or agreed with the statement that they consider themselves experts on taxes, only $6 \%$ strongly disagreed or disagreed with it, and the 
remaining 38\% were neutral. Thanks to the high expertness of respondents, we can consider their answers relevant for our research. Applying the methodology described in previous section, the weights of individual tax categories on the overall tax burden were calculated and are displayed in Table 2.

Table 2. Calculated weights and order of the WTI categories

\begin{tabular}{|c|c|c|c|c|c|}
\hline & PIT & CIT & VAT & PRO & OTC \\
\hline Weight & 0.3505 & 0.1927 & 0.0730 & 0.1912 & 0.1926 \\
\hline Order & 1 & 2 & 5 & 4 & 3 \\
\hline
\end{tabular}

The most important category in WTI for Slovakia is Personal Income Tax with contribution of $35.5 \%$. It is then followed by Corporate Income Tax, Excises and Property Taxes with the similar contribution around 19\%. The least important is Value Added Tax with contribution only $7.3 \%$. It is in line with expectation, that direct taxes are the ones, that bothers economic subjects the most. Overall, direct taxes contribute by $73.58 \%$ to tax burden, while indirect taxes only by $26.42 \%$. Therefore, policy makers should carefully prepare reforms of direct taxes. In Slovakia, the government should definitely think about reversing the trend in PIT, which is the most important category in tax burden. In case of need for increasing tax revenues, the politicians might consider firstly value added tax, which is stable over the period and the least bothering at the same time.

Table 3 displays the value of WTI for Slovakia for years 2000-2019. It is a unique single weighted average tax rate for the country, which can be simply incorporated into models of economic growth. The rate is quite stable over time, but in average, the tax burden in Slovakia is higher in the second decade of the examined period.

Table 3. WTI for Slovakia in period 2000-20219

\begin{tabular}{|c|c|c|c|c|c|c|c|c|c|}
\hline $\mathbf{2 0 0 0}$ & $\mathbf{2 0 0 1}$ & $\mathbf{2 0 0 2}$ & $\mathbf{2 0 0 3}$ & $\mathbf{2 0 0 4}$ & $\mathbf{2 0 0 5}$ & $\mathbf{2 0 0 6}$ & $\mathbf{2 0 0 7}$ & $\mathbf{2 0 0 8}$ & $\mathbf{2 0 0 9}$ \\
\hline $21.79 \%$ & $21.48 \%$ & $20.64 \%$ & $20.71 \%$ & $20.87 \%$ & $19.73 \%$ & $20.09 \%$ & $19.85 \%$ & $20.07 \%$ & $20.29 \%$ \\
\hline $\mathbf{2 0 1 0}$ & $\mathbf{2 0 1 1}$ & $\mathbf{2 0 1 2}$ & $\mathbf{2 0 1 3}$ & $\mathbf{2 0 1 4}$ & $\mathbf{2 0 1 5}$ & $\mathbf{2 0 1 6}$ & $\mathbf{2 0 1 7}$ & $\mathbf{2 0 1 8}$ & $\mathbf{2 0 1 9}$ \\
\hline $19.71 \%$ & $20.03 \%$ & $20.28 \%$ & $21.07 \%$ & $20.78 \%$ & $21.25 \%$ & $21.47 \%$ & $21.16 \%$ & $20.84 \%$ & $21.13 \%$ \\
\hline
\end{tabular}

\section{Discussion}

Now, let's compare the newly designed World Tax Index for Slovakia with Tax quota. Figure 2 displays their values for last 20 years. World Tax Index was more stable, which might suggest it was not affected by decline in GDP caused by the latest global financial crisis and therefore the problem commented by Kotlán and Machová (2012) might be removed with new methodology. The tax rates during period of 2004-2012 was quite stable due to flat tax rate and therefore we might expect the tax burden be the same, but the tax quota was declining which suggests it was affected by the changes in GDP. The results of this research are limited by number of respondents and it would be interesting to estimate the tax burden with more observation.

Overall, the results are in line with the study prepared by the OECD (2011). The study suggests the moving from direct to indirect taxation, which is the main trend in fiscal policy. 


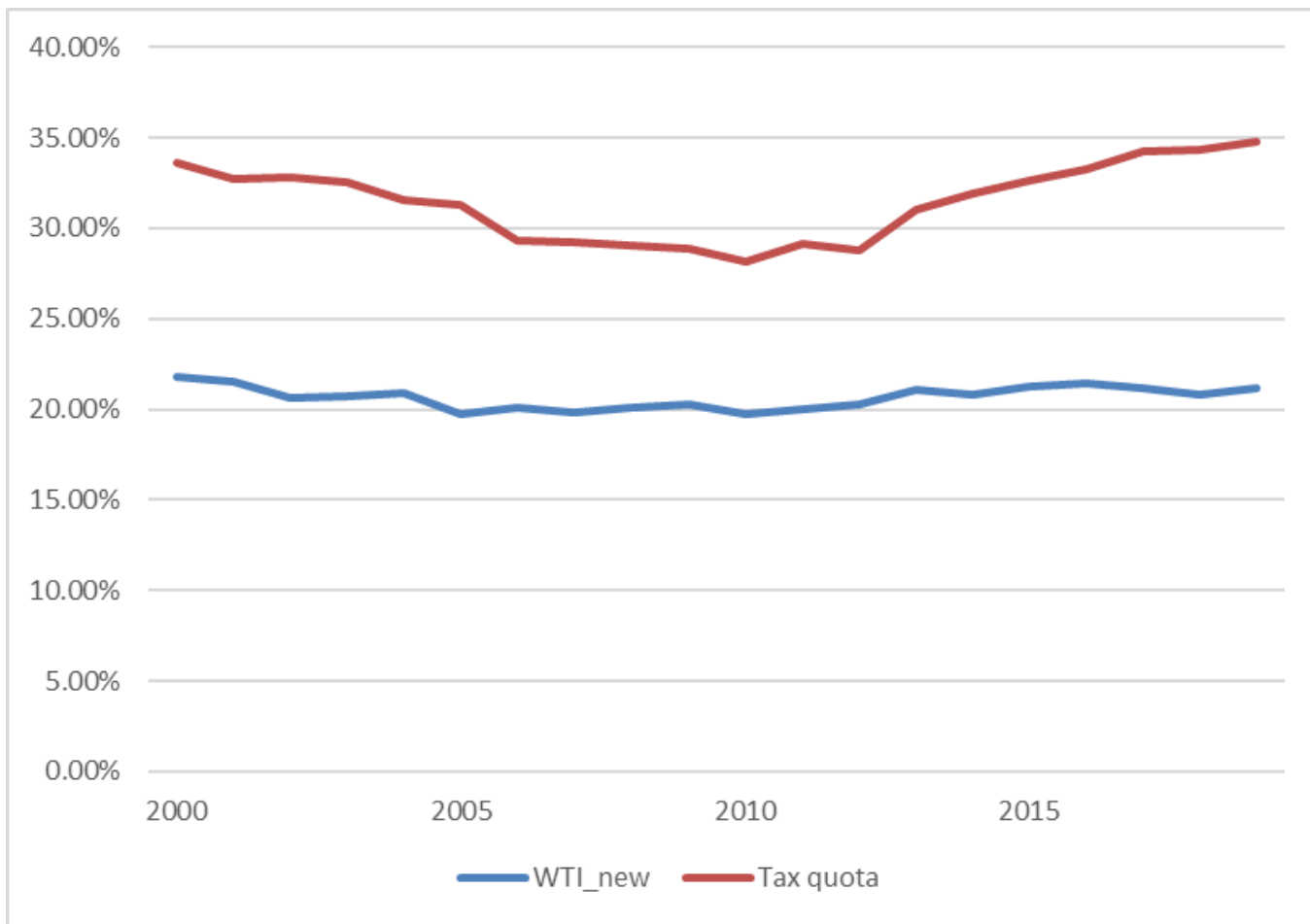

Figure 2. World Tax Index and Tax quota for Slovakia

Direct taxes bother economic subjects much more than indirect. Policy makers should follow it in order to collect taxes efficiently and reduce tax burdens. In more detail, the study stated that corporate and personal income taxes had the largest negative effects on the economy, while in contrast consumption and property taxes had the smallest negative effects, same as our results. Corporate and personal income taxes are the most important categories and consumption and property taxes are on the opposite side.

Acknowledgments: Supported by funding of specific research at Faculty of Economics and Administration, project MUNI/A/0906/2019. This support is gratefully acknowledged.

\section{References}

Borsboom, D., Mellenbergh, G. J, \& van Heerden, J. (2003). The theoretical status of latent variables. Psychological Review, 110(2), 203-219. https://doi.org/10.1037/0033-295X.110.2.203

Brown, J. D. (2009). Principal components analysis and exploratory factor analysis - Definitions, differences and choices. Shiken: JALT Testing \& Evaluation SIG Newsletter, 13(1), 26-30. http://jalt.org/test/PDF/Brown29.pdf

De Laet, J. P., \& Wöhlbier, F. (2008). Tax burden by economic function: A comparison for the EU member states.

(MPRA Paper 14761). Munich Personal RePEc Archive. https://mpra.ub.unimuenchen.de/14761/1/MPRA_paper_14761.pdf

Eurostat. (2020). Harmonised index of consumer prices (HICP) [Data set]. Retrieved November 30, 2020, from https://ec.europa.eu/eurostat/web/hicp/data/database

Kiss, G. P., Jedrzejowicz, T., \& Jirsáková, J. (2009). How to measure tax burden in an internationally comparable way? (NBP Working Paper 56). National Bank of Poland. https://www.nbp.pl/publikacje/materialy_i_studia/56_en.pdf

Kiss, G. P., Jedrzejowicz, T., \& Jirsakova, J. (2009). How to Measure Tax Burden in an Internationally Comparable Way? SSRN Electronic Journal. https://doi.org/10.2139/ssrn.1752229

Kotlán, I., \& Machová, Z. (2012). World Tax Index: Methodology and data. DANUBE: Law and Economics Review, 2(2), 19-33. https://www.eaco.eu/wp-content/uploads/2015/04/kotlan_machova2.pdf 
Kotlán, I., \& Machová, Z. (2013). The impact of the tax burden on the living standard in OECD countries. Ekonomický časopis, 61(9), 951-962. https://www.sav.sk/journals/uploads/0621141609\%2013\%20KotlanMachova-RS.pdf

Kotlán, I., Machová, Z., \& Janíčková, L. (2011). Vliv zdanění na dlouhodobý ekonomický růst. Politická ekonomie, 59(5), 638-658. https://polek.vse.cz/pdfs/pol/2011/05/04.pdf

Konôpková, Z., \& Buček, J. (2016). World Tax Index: Methodology for 2017. In Z. Machová (Ed.), 6th International Scientific Conference TAXES IN THE WORLD (pp. 77-87). European Association Comenius EACO and VSEO.

Konôpková, Z., \& Buček, J. (2018a). World Tax Index: Measuring tax burden in the Czech Republic. In M. Reiff, \& P. Gežík (Eds.), Quantitative methods in economics; Multiple criteria decision making XIX (pp. 186-192). University of Economics. http://fhi.sk/files/katedry/kove/ssov/proceedings/Zbornik2018.pdf

Konôpková, Z., \& Buček, J. (2018b). World Tax Index: Results of the pilot project. In L. Váchová, \& V. Kratochvíl (Eds.), The 36th International Conference Mathematical Methods in Economics, Conference Proceedings (pp. 240245). MatfyzPress. https://mme2018.fm.vse.cz/wp-content/uploads/2018/09/MME2018-

Electronic_proceedings.pdf

OECD. (2011). Tax Policy Reform and Economic Growth. OECD Publishing. https://doi.org/10.1787/9789264091085en

OECD. (2020). Database OECD [Data set]. Retrieved November 30, 2020, from https://www.oecd.org/tax/taxpolicy/tax-database/

Polito, V. (2009). Measuring the Effective Tax Burden in the Real World. Fiscal Studies, 30(2), 247-278. https://doi.org/10.1111/j.1475-5890.2009.00095.x

Raimondos-Møller, P., \& Woodland, A. D. (2006). Measuring Tax Efficiency: A tax optimality index. Journal of Public Economics, 90(12), 1903-1922. https://doi.org/10.1016/j.jpubeco.2005.12.003

Zákonypreludi.sk. (2020, August 31). Zákony pre l'udí. https://www.zakonypreludi.sk/zz/1992-318\#cast3 